\title{
Haematological and biochemical changes after exposure to Maerua crassifolia ethanol leaf extract in rats
}

\author{
Akuodor Godwin Christian ${ }^{1}$, Eban Linus Kechi ${ }^{2}$, Nku Clement Oshie $^{3}$, Aja Daniel Ogbonna John ${ }^{1}$, \\ Ezeunala Mercy Nwakaego ${ }^{4}$, Ajoku Gloria Ahunna ${ }^{4}$, Nwobodo Ndubuisi Nwobodo ${ }^{1}$ \\ ${ }^{1}$ Department of Pharmacology and Therapeutics, Faculty of Medicine, Ebonyi State University, Abakaliki, Nigeria. \\ ${ }^{2}$ Department of Pharmacology, Faculty of Basic Medical Sciences, College of Medical Sciences, University of Calabar, Calabar, Nigeria. \\ ${ }^{3}$ Department of Physiology, Faculty of Basic Medical Sciences, College of Medical Sciences, University of Calabar, Nigeria. \\ ${ }^{4}$ Department of Microbiology and Biotechnology, National Institute for Pharmaceutical Research and Development (NIPRD), Abuja, Nigeria.
}

\begin{tabular}{|c|c|}
\hline ARTICLE INFO & ABSTRACT \\
\hline $\begin{array}{l}\text { Article history: } \\
\text { Received on: } 12 / 03 / 2017 \\
\text { Accepted on: } 19 / 04 / 2017 \\
\text { Available online: } 30 / 06 / 2017\end{array}$ & $\begin{array}{l}\text { This study was carried out to determine the safety profile of Maerua crassifolia by conducting the acute and } \\
\text { subacute toxicological assay of its ethanol leaf extract in rats. The animals were treated daily with the leaf } \\
\text { extract at doses of } 100,200 \text { and } 400 \mathrm{mg} / \mathrm{kg} \text { orally for } 14 \text { and } 28 \text { days. Rats used as control were given distilled } \\
\text { water and all rats weighed every } 7 \text { days. After the test, haematological and biochemical parameters as well as }\end{array}$ \\
\hline $\begin{array}{l}\text { Key words: } \\
\text { Maerua crassifolia; Leaf } \\
\text { extract; Haematological; } \\
\text { Biochemical; organ weight; } \\
\text { Rats. }\end{array}$ & $\begin{array}{l}\text { animals compared to control in both studies. In the acute toxicity test, the extract did not cause any signs of } \\
\text { toxicity or produce mortality in rats. Subacute results showed that oral administration of the leaf extract did not } \\
\text { significantly ( }<0.05 \text { affect their food consumption, haematological and biochemical parameters and relative } \\
\text { organs weight. Findings in this study showed that Maerua crassifolia is endowed with the potential beneficial } \\
\text { effects as immune booster and protecting the liver and kidney systems. }\end{array}$ \\
\hline
\end{tabular}

\section{INTRODUCTION}

Maerua crassifolia Forssk (Capparaceae) is widely used in ethnomedicine for the treatment of different diseases. In traditional medicine, the leaves are used for the treatment of some diseases including analgesic, anti-inflammatory, antipyretic, antibacterial and antioxidant, antimalarial, Phytochemical and antidiarrhoea (Akuodor et al., 2016; Chilaka et al., 2015; Akuodor et al., 2014a; Akuodor et al., 2014d). In other pharmacological studies, the leaf extract has shown to have effects against gastrointestinal and toothache diseases (Rahman et al., 2004; Idris-Usman et al., 2010). The presence of different biologically active constituents like alkaloids, terpenoids,

\footnotetext{
* Corresponding Author

Dr. Akuodor GC, Department of Pharmacology and Therapeutics, Faculty of Medicine, Ebonyi State University, Abakaliki, Nigeria. E-mail: goddyakuodor@yahoo.com; Tel.+2348036725237.
}

tannins, flavonoids, saponins and cardiac glycosides have been revealed in the phytochemical analysis of the leaves (Akuodor et al., 2014 d). Despite the wide use of medicinal plants, their safety and potency have not been fully investigated and more detailed screening is therefore, needed for evaluation and standardization of herbal formulations (WHO, 2008). Due to wide application and the prolonged intake of $M$. crassifolia leaf, the present study was therefore designed to study the acute and subacute toxicity profile of ethanol leaf extract of $M$. crassifolia in experimental rats.

\section{MATERIALS AND METHODS}

\section{Collection of test plant}

Leaf samples of Maerua crassifolia were collected from Sokoto, North West, Nigeria in March 2009 and were identified by a taxonomist in Department of Medicinal Plant research and Traditional Medicine, NIPRD, Abuja, Nigeria, where the voucher specimen was deposited (NIPRD/H/6406). 


\section{Preparation of Maerua crassifolia extract}

All the samples of the plant (leaves) were rinsed thoroughly in distilled water and air-dried at room temperature. The plant sample $(350 \mathrm{~g})$ was then ground to fine powder and soaked in absolute ethanol for $24 \mathrm{~h}$ with constant agitation. The extract was filtered with Whatman no. 1 paper, the filtrate was dried on a water bath under reduced pressure. The yield of the ethanol extract was $10.35 \%$ of the dry weight.

\section{Experimental animals}

Male and female wistar albino rats were used for the acute and subacute toxicology studies. The rats were obtained from animal house of University of Nigeria, Nsukka, Enugu State. Animals were acclimatized to laboratory conditions for 14 days before the experiments. During their acclimatization, rats were housed in cages with pellet diet and clean water. All procedures in the study were performed according to NIH Guide for the Care and Use of Laboratory Animals (National Institute of Health, 2011).

\section{Acute toxicity study}

Oral acute toxicity test was performed using the Organization of Economic Cooperation and Development (OECD) guideline for testing of chemicals (OECD, 2002). Male and female rats weighing 180-200 g were used for this study which was conducted in two phases. Three groups of 3 rats in each cage were administered 100,600 and $1000 \mathrm{mg} / \mathrm{kg}$ of the extract orally. Observation for signs of toxicity and mortality was made for 24 hrs with special attention given to the first $4 \mathrm{hrs}$. This was followed by administration of the leaf extract $(2000,3000$ and $5000 \mathrm{mg} / \mathrm{kg})$ to the next three groups of 3 rats and equally observed as earlier stated, and daily for 7 days for any signs of delayed toxicity.

\section{Subacute oral toxicity study}

The study was conducted according to OECD test guideline 407 (OECD, 1995). A total of twenty-four rats (12 males and 12 females) were weighed and grouped into 4 of 3 male and 3 female rats in each group (the males were separated from the females) for this study. The animals were grouped based on three different treatment doses of the leaf extract and one control (distilled water) group. The rats were orally treated daily with Maerua crassifolia leaf extract at doses of 100, 200 and 400 $\mathrm{mg} / \mathrm{kg}$, and distilled water for 28 days.

The treatment doses representing the pharmacological active dose which was the most effective dose observed in the evaluation of the analgesic, anti-inflammatory and antipyretic (Akuodor et al., 2016), antimalarial (Akuodor et al., 2014 a) and antidiaorrhoeal activities of Maerua crassifolia leaf extract in rats (Akuodor et al., 2014 d). At the end of the 28 days treatment period, the rats were deprived of pellet but had free access to drinking water for $24 \mathrm{hrs}$ before being sacrificed under inhaled chloroform anaesthesia. Blood samples were collected through cardiac puncture into EDTA and nonheparinized containers for haematological and biochemical analysis, respectively. The organs were excised, weighed and macroscopically examined.

\section{Body and relative organ weight measurement}

The rats were weighed weekly throughout the duration of the study and percentage change in weight for each rat at the end of the study was calculated as:

percentage change in weight $=($ Different between interval body weight and initial body weight/ initial weight) $\times 100$.

The relative organ body weight (ROW) of each harvested organ was calculated as:

$$
\text { ROW }=(\text { organ weight/total body weight }) \times 100 .
$$

\section{Haematological analysis}

Blood samples were collected and analyzed using automated haematology analyzer (Mythic 18 by Orphee, Switzerland). Parameters checked include pack cell volume (PCV), Hemoglobin (HB), red blood cell (RBC) count, platelet count (PLT), white blood cell (WBC) count, mean corpuscular volume $(\mathrm{MCV})$, mean corpuscular haemoglobin $(\mathrm{MCH})$, mean corpuscular haemoglobin concentration (MCHC).

\section{Biochemical analysis}

Serum blood samples were analyzed for alkaline phosphatase (ALP), alanine transaminase (ALT), aspartate transaminase (AST), albumin (Alb), total protein (TP), total bilirubin (T-Bili) and direct bilirubin (D-Bili), urea (Bu), creatinine (Crea) using ( Gesan Chem 200, USA) automated machine.

\section{Statistical analysis}

All the results were expressed as mean values \pm SEM. One-way analysis of variance (ANOVA) was performed to compare the differences between two or more means followed by Dennett's post tests using SPSS version 20.0. A mean difference was considered significant when $\mathrm{p}<0.05$.

\section{RESULTS}

\section{Acute oral toxicity}

The ethanol leaf extract produced no adverse effect in rats at the dose levels tested. There were no changes in behavior patterns, nature of stool and salivation of the rats. There was no mortality observed in the different groups of rats after 7 days. The oral $\mathrm{LD}_{50}$ value of the plant was estimated to be greater than 5000 $\mathrm{mg} / \mathrm{kg}$.

\section{Effect of the extract on body weight}

Table 1 showed that the leaf extract compared to control caused no significant increase in the percentage body weight in the 28 day experimental period. 
Table 1: Effect of Maerua crassifolia leaf extract on body weight changes in rats.

\begin{tabular}{ccccc}
\hline Days & Control & $\mathbf{1 0 0} \mathbf{~ m g / k g}$ & $\mathbf{2 0 0} \mathbf{~ m g} / \mathbf{k g}$ & $\mathbf{4 0 0} \mathbf{~ m g} / \mathbf{k g}$ \\
\hline Day 0 & $242.3 \pm 13.40$ & $240.59 \pm 13.30$ & $242.8 \pm 15.60$ & $241.90 \pm 13.45$ \\
Day 7 & $241.7 \pm 16.70$ & $239.68 \pm 17.00$ & $244.38 \pm 17.10$ & $245.80 \pm 10.9$ \\
Day 14 & $243.30 \pm 17.60$ & $242.00 \pm 15.5$ & $245.90 \pm 18.60$ & $247.70 \pm 17.59$ \\
Day 21 & $245.00 \pm 17.82$ & $244.54 \pm 18.26$ & $246.60 \pm 19.49$ & $247.65 \pm 15.76$ \\
Day 28 & $246.95 \pm 17.30$ & $246.00 \pm 15.44$ & $248.50 \pm 16.12$ & $249.70 \pm 13.55$ \\
\hline
\end{tabular}

Results are presented as the means \pm SEM $(n=6)$. All values were not significantly different from control at $\mathrm{p}<0.05$.

Table 2: Effect of Maerua crassifolia leaf extract on haematological parameters in rats.

\begin{tabular}{|c|c|c|c|c|}
\hline Parameter & Control & $100 \mathrm{mg} / \mathrm{kg}$ & $200 \mathrm{mg} / \mathrm{kg}$ & $400 \mathrm{mg} / \mathrm{kg}$ \\
\hline White blood cell (x 109/L) & $6.10 \pm 0.52$ & $6.56 \pm 0.20$ & $7.65 \pm 0.11$ & $5.91 \pm 0.87$ \\
\hline Pack cell volume $(\%)$ & $39.72 \pm 1.28$ & $40.70 \pm 1.17$ & $40.82 \pm 1.41$ & $40.95 \pm 1.45$ \\
\hline Red blood cell $\left(\times 10^{12} / \mathrm{L}\right)$ & $6.65 \pm 0.31$ & $6.66 \pm 0.22$ & $7.43 \pm 0.61$ & $7.53 \pm 0.65$ \\
\hline Haemoglobin (g/dL) & $12.60 \pm 0.58$ & $13.46 \pm 0.19$ & $13.62 \pm 0.28$ & $13.83 \pm 18$ \\
\hline Mean corpuscular volume (fl) & $54.35 \pm 0.81$ & $58.65 \pm 1.20$ & $60.48 \pm 1.59$ & $65.10 \pm 1.08$ \\
\hline Mean cell haemoglobin (pg) & $17.84 \pm 0.43$ & $17.70 \pm 0.23$ & $18.17 \pm 0.22$ & $18.20 \pm 0.36$ \\
\hline Mean cell haemoglobin concentration (g/dl) & $31.39 \pm 0.51$ & $30.64 \pm 0.22$ & $30.80 \pm 0.59$ & $32.33 \pm 0.19$ \\
\hline Platelet $\left(\times 10^{9} / \mathrm{L}\right)$ & $625.16 \pm 12.22$ & $591.20 \pm 20.12$ & $608.21 \pm 31.48$ & $632.45 \pm 33.50$ \\
\hline Neutrophils (\%) & $36.30 \pm 1.90$ & $37.85 \pm 2.64$ & $40.11 \pm 2.61$ & $40.07 \pm 2.49$ \\
\hline Lymphocytes (\%) & $62.56 \pm 2.44$ & $65.39 \pm 2.77$ & $58.33 \pm 2.67$ & $60.50 \pm 1.66$ \\
\hline Monocytes $(\%)$ & $1.05 \pm 0.30$ & $0.74 \pm 0.22$ & $1.15 \pm 0.40$ & $1.20 \pm 0.37$ \\
\hline Eosinophils (\%) & $0.41 \pm 0.23$ & $0.61 \pm 0.24$ & $0.70 \pm 0.35$ & $80 \pm 0.21$ \\
\hline
\end{tabular}

Results are presented as the means \pm SEM $(n=6)$. All values were not significantly different from control at $\mathrm{p}<0.05$.

Table 3: Effect of Maerua crassifolia leaf extract on serum biochemical parameters in rats.

\begin{tabular}{lcccc}
\hline Parameter & Control & $\mathbf{1 0 0}$ & $\mathbf{2 0 0}$ & $\mathbf{4 0 0}$ \\
\hline Alkaline phosphatase (U/L) & $85.28 \pm 2.85$ & $88.30 \pm 2.61$ & $86.22 \pm 2.22$ & $85.90 \pm 1.66$ \\
Aspatate transaminase (U/L) & $55.38 \pm 3.69$ & $62.04 \pm 3.73^{*}$ & $56.82 \pm 3.61$ & $60.01 \pm 4.19$ \\
Alanine transaminase (U/L) & $19.00 \pm 2.67$ & $22.77 \pm 2.37^{*}$ & $21.70 \pm 2.70$ & $21.68 \pm 2.72$ \\
Albumine (mg/dL) & $3.45 \pm 0.38$ & $4.00 \pm 0.19$ & $3.91 \pm 0.17$ & $3.89 \pm 0.15$ \\
Total protein (mg/dL) & $7.55 \pm 0.30$ & $8.16 \pm 0.22^{*}$ & $8.20 \pm 0.18^{*}$ & $8.18 \pm 0.25^{*}$ \\
Total bilirubin (U/L) & $1.10 \pm 0.33$ & $1.52 \pm 0.26$ & $1.68 \pm 0.30$ & $1.40 \pm 0.19$ \\
Direct bilirubin (U/L) & $0.55 \pm 0.14$ & $0.68 \pm 0.10$ & $0.62 \pm 0.14$ & $0.59 \pm 0.11$ \\
\hline
\end{tabular}

Results are presented as the means \pm SEM $(n=6)$. Significant at $* \mathrm{P}<0.05 ; * * \mathrm{P}<0.01$ when compared to control.

Table 4: Effect of Maerua crassifolia leaf extract on kidney functions in rats.

\begin{tabular}{|c|c|c|c|c|}
\hline Parameter & Control & $100 \mathrm{mg} / \mathrm{kg}$ & $200 \mathrm{mg} / \mathrm{kg}$ & $400 \mathrm{mg} / \mathrm{kg}$ \\
\hline Sodium (meq/L) & $142.07 \pm 2.58$ & $144.53 \pm 2.50$ & $143.49 \pm 3.10$ & $140.22 \pm 3.40$ \\
\hline Potassium (meq/L) & $4.90 \pm 0.19$ & $4.78 \pm 0.76$ & $4.56 \pm 0.65$ & $3.86 \pm 0.88$ \\
\hline Chloride (meq/L) & $110.49 \pm 3.15$ & $108.09 \pm 4.54$ & $105.50 \pm 3.86$ & $101.77 \pm 4.92$ \\
\hline Bicarbonate (meq/L) & $24.38 \pm 1.22$ & $24.40 \pm 1.42$ & $23.61 \pm 1.49$ & $23.31 \pm 1.40$ \\
\hline Urea (mg/dL) & $27.80 \pm 3.96$ & $24.66 \pm 2.80$ & $24.33 \pm 3.07$ & $23.67 \pm 4.23$ \\
\hline Creatinine $(\mathrm{mg} / \mathrm{dL})$ & $1.00 \pm 0.31$ & $0.94 \pm 0.22$ & $0.88 \pm 0.17$ & $0.85 \pm 0.20$ \\
\hline
\end{tabular}

Results are presented as the means \pm SEM $(n=6)$. All values were not significantly different from control at $p<0.05$.

Table 5: Effect of Maerua crassifolia leaf extract on relative organ weights in rats.

\begin{tabular}{lcccc}
\hline Organs & Control & $\mathbf{1 0 0} \mathbf{~ m g} / \mathbf{k g}$ & $\mathbf{2 0 0} \mathbf{~ m g} / \mathbf{k g}$ & $\mathbf{4 0 0} \mathbf{~ m g} / \mathbf{k g}$ \\
\hline Heart & $0.43 \pm 0.03$ & $0.40 \pm 0.03$ & $0.37 \pm 0.04$ & $0.39 \pm 0.04$ \\
Lungs & $0.80 \pm 0.05$ & $0.84 \pm 0.10$ & $0.96 \pm 0.06$ & $0.90 \pm 0.04$ \\
Kidneys & $0.66 \pm 0.04$ & $0.70 \pm 0.01$ & $0.66 \pm 0.05$ & $0.64 \pm 0.03$ \\
Liver & $3.08 \pm 0.14$ & $3.75 \pm 0.10^{* *}$ & $3.55 \pm 0.12^{*}$ & $3.45 \pm 0.10^{*}$ \\
Spleen & $0.50 \pm 0.03$ & $0.43 \pm 0.02$ & $0.42 \pm 0.02$ & $0.41 \pm 0.01$ \\
Testes & $1.85 \pm 0.15$ & $1.69 \pm 0.09$ & $1.47 \pm 0.06$ & $1.33 \pm 0.03$ \\
Brain & $1.20 \pm 0.10$ & $1.08 \pm 0.05$ & $1.00 \pm 0.04$ & $0.88 \pm 0.02$ \\
\hline Ren
\end{tabular}

Results are presented as the means \pm SEM $(\mathrm{n}=6)$. Significant at $* \mathrm{P}<0.05 ; * * \mathrm{P}<0.01$ when compared to control.

\section{Effect of the extract on haematological parameters}

Table 2 shows the effects of $M$. crassifolia extract on the hematological parameters in sub-acute study. All other hematological parameters showed no significant changes and remained within physiological range after the 28-day treatment period.

\section{Effect of the extract on biochemical parameters}

The effect of sub-acute administration of $M$. crassifolia extract on biochemical parameters is presented in Table 3. All biochemical parameters showed normal levels in both the extract treated and control rats.

\section{Relative organ weights}

As shown in table 5, there was no significant difference in the weight of organs between the extract treated and control groups throughout the treatment period. 


\section{DISCUSSION}

Medicinal plants have been globally adapted as basis for the treatment of different human diseases (Afolabi et al., 2012). In evaluating medicinal plants for pharmacological activity, screening of toxic characteristics of the compounds is considered first. Apart from numerous pharmacological beneficial activities of Maerua crassifolia, comprehensive knowledge concerning the toxicological effect of the leaf has not been examined. Therefore, the present study was carried out to ascertain the acute and subacute toxicity of $M$. crassifolia in experimental animal.

The absence of mortality at oral treatment above 5000 $\mathrm{mg} / \mathrm{kg}$, shows that the ethanol leaf extract is non toxic acutely. However, the food and water consumption were not altered during the study when compared to control group. In addition, the food and water intakes were properly accepted by the experimental rats exposed to $M$. crassifolia leaf extract which suggest that the extract may not have caused any alteration in diets metabolism in these animals. There was no significant increase in body weight in all animals administered with $M$. crassifolia leaf extract. Furthermore, the observed body weight increase could be attributed to the nutritive constituents in the extract (Ezeonwumelu et al., 2011).

Evaluation of blood parameters can be used to determine the level of negative effect of foreign compounds, including medicinal plants (Ibrahim et al., 2016; Agbaje et al., 2009). This method can also be used to explain haematological relating functions of plant products (Yakubu et al., 2007). In addition, such investigation is necessary to risk examination as changes in the blood system have higher predictive value human toxicity when data are explained from animal studies (Olson et al., 2000). Haematological analysis was carried out for both $M$. classifolia extract treated and control groups, and their results show no significant effects. The non significant activity of the leaf extract on RBC, MCH, MCV, MCHC and PLT shows that M. classifolia does not affect erythropoiesis and osmotic fragility of the red blood cells (Guyton and Hall, 2006). The white blood cells (WBC) are the first line of defence which responds to infectious agents, inflammatory process or tissue injury. More so, there was no significant changes observed in the neutrophils, lymphocytes and monocytes in $M$. classifolia leaf extract treated animals, and this confirmed the finding further. The serum biochemical analyses were done to check for possible alterations in renal and hepatic functions in order to find possible pathological changes and nature of disease of extract treated compared to control rats. Renal and hepatic function analysis is highly useful in the toxicity screening of medicine and plant extracts as both are important for the survival of an organism (Olorunisola et al., 2012). M. classifolia leaf extract did not show significant changes in all the biochemical parameters which suggest that sub-acute administration of the extract does not affect rats hepatocyte function. Renal dysfunction can be assayed by continuous measurements of urea, creatinine and uric acid and their normal values reflect at decreased likelihood of renal challenges (Davis and Bredt, 1994). However, decrease in internal weight of an organ is an expression of toxicity resulting from exposure to toxic substances (Adeyemi et al., 2010). The results of this study showed that the important organs like liver, kidney, lungs, spleen and heart were not adversely affected throughout the 28 day treatment period. Therefore, since the relative organ weight of the treated rats showed no significant alteration, it could be said that the leaf extract is nontoxic to the organs of the treated compared to control rats in the sub-acute study.

\section{CONCLUSION}

The findings from this study suggest that ethanol leaf extract of $M$. classifolia does not possess the toxic effects that could compromise its medicinal use as an herbal medicine. Prolonged administration showed effects which suggest that the leaf extract produced no toxic effects with respect to haematological and biochemical parameters and relative organ weights of rats. The observed results also suggest that the extract may possess immune boosting properties and protecting the liver and kidney systems. These findings suggest that $M$. classifolia leaf extract may not produce adverse effects and is safe for medicinal purpose.

Ethical Approval: All authors hereby declare that "Principles of laboratory animal care" (NIH, 2011) were followed. Approval for this study was obtained from the appropriate ethics committee.

\section{ACKNOWLEDGEMENT}

The authors are grateful to Mr. Simon Eze Nwibo for his technical assistance.

\section{Financial support and sponsorship: Nil.}

Conflict of Interests: There are no conflicts of interest

\section{REFERENCES}

Adeyemi OO, Akindele AJ, Nwumeh KI. Acuteandsubchronictox- icological assessmentof Byrsocarpus coccineus Schum. And Thonn. (Con-naraceae) aqueous leaf extract. Int. J. Appl. Res. Nat. Prod., 2010; 3,1-11.

Afolabi SO, Akindele AJ, Awodele O, Anunobi CC and Adeyemi OO. A 90 day chronic toxicity study of Nigerian herbal preparation DAS-77 in rats. Complementary and Alternative Medicine, 2012; $12: 79$

Agbaje EO, Adeneye A A, and Daramola A O. Biochemical and Toxicological Studies of Aqueous Extract of Syzigium Aromaticum (L.) Merr. \& Perry (Myrtaceae) in Rodents. Afri J. Tradit Complemen Altern Med. 2009; 6(3): 241-254.

Akuodor GC, Essien DA, Akpan JL, Chilaka KC, Uwaezuoke NJI, Nwadike KI, Nwobodo NN, Ezeokpo BC. Analgesic, antiinflammatory and antipyretic activities of methanolic leaf extract of Maerua crassifolia. Journal of Coastal Life Medicine. 2016; 4(3): 930935.

$\mathrm{KC}$

Akuodor GC, Essiet GA, Ajoku GA, Ezeunala MN, Chilaka

Antimalarial Potency of the methanol leaf extract of Maerua crassifolia Forssk (Capparaceae). Asian Pacific Journal of Tropical Disease. 2014a 4(1):35-39. 
Akuodor GC, Ibrahim JA, Akpan JL, Okorie AU, Ezeokpo BC.

Phytochemical and antidiarrhoeal properties of methanolic leaf extract of Maerua crassifolia Forssk. European Journal of Medicinal Plants. 2014d; 4(10): 1223-1231. Ezeokpo BC

Chilaka KC, Akuodor GC, Akpan JL, Ogiji ED, Eze CO,

Antibacterial and antioxidant activities of methanolic leaf extract of Maerua crassifolia. Journal of Applied Pharmaceutical Sciences. 2015; 5(10):147-150.

Davis ME and Bredt ND. Renal methods for toxicity, in Principles and Methods of Toxicology, Raven Press. 1994 New York, NY, USA.

Ezeonwumelu JOC, Julius AK, Muhoho CN, Ajayi AM, Oyewale AA, Tanayen JK, Balogun SO, Ibrahim A, Adzu B, Adiukwu CP, Oloro J, Kiplagat DM, Goji ADT, Okoruwa AG, Onchweri AN, Reddy PMK. Biochemical and Histological Studies of Aqueous Extract of Bidens pilosa Leaves from Ugandan Rift Valley in Rats.Br. J. Pharmacol. Toxicol. 2011; 2(6):302-309.

Guyton AC and Hall JE. 2006. TextbookofMedicalPhysiology, 11thed.Elsevier Saunders, USA. 2006 p.1152.

Ibrahim MB, Sowemimo AA, Sofidiya MO, Badmos KB, Fageyinbo MS, Abdulkareem FB, Odukoya OA. 2016. Sub-acute and chronic toxicity profiles of Markhamia tomentosa ethanolic leaf extract in rats. Journal of Ethnopharmacology , 193:68-75.

Idris-Usman MS, Akuodor GC, Idris HS, Akpan JL, Ugwu TC, Anyalewechi NA, Osunkwo UA. 2010. Gastrointestinal properties of the ethanolic leaf extract of Maerua crassiflia. African Network for Drugs and Diagnostic Innovation (ANDI), Nairobi, Kenya. 2010; PP. 63

National Institute of Health (NIH). 2011. Committee for the Update of the Guide for the Care and Use of Laboratory Animals. Washington (DC): National Academies Press (US).

Olorunnisola OS, Bradley G and Afolayan AJ. Acute and subchronic toxicity studies of methanolic extract of Tulbaghia violacea rhizomes in Wistar rats, African Journal of Biotechnology. 2012; 11: 14934-14940.
Olso H, Betton G, Robinson D,Thomas K, Monro A, Kolaja G, Lilly P, Sanders J Sipes G, Bracken W, Dorato M, Deun KV, Smith P, Berger B, Heller A. Concordance of the toxicity of pharmaceuticals in humans and in animals. Regul.Toxicol.Pharmacol. 2000; 32, 56-67.

Organisation for Economic Cooperation and Development (OECD). Guidelines for the Testing of Chemicals/Section 4: Health Effects Test No. 423, Acute oral toxicity-acute toxic class method, Paris. 2002. OECD.

Organisation for Economic Cooperation and Development (OECD). OECD guidelines for testing of chemicals: Guideline 407: Repeated dose 28-day oral toxicity in rodents. Office of Economic and Community Development, Paris. 1995.

Rahman MA, Mossa JS, Al-Said MS, Al-Yahya MA. Medicinal plant diversity in the flora of Saudi Arabia 1: a report on seven plant families. Fitoterapia. 2004; 75: 145-61.

World Health Organization (WHO). Traditional Medicine Fact sheet 2008; No. 134. Retrieved from: www.who.int/mediacentre/factsheets/fs134/en/

Yakubu MT, Akanji MA and Oladiji AT. Haematological evaluation in male albino rats following chronic administration of aqueous extract of Fadogia agrestis stem, Pharmacognosy Magazine. 2007; 3: 3438.

\section{How to cite this article:}

Christian AG, Kechi EL, Oshie NC, John ADO, Nwakaego EM, Ahunna AG, Nwobodo NN. Haematological and biochemical changes after exposure to Maerua crassifolia ethanol leaf extract in rats. J App Pharm Sci, 2017; 7 (06): 136-140. 